\title{
DIE VERBAND TUSSEN ENKELE DIMENSIES VAN LOOPBAANANKERS, POSPERSEPSIE EN GEHALTE VAN WERKLEWE
}

\author{
A.M.G. SCHREUDER \\ J. FLOWERS \\ Departement Bedryfsielkunde, \\ Universiteit van Suid-Afrika
}

\begin{abstract}
The relationship between certain dimensions of career anchors, job perceptions and quality of work life. The career anchors and job perceptions of a sample of 258 employees in various types of organizations (private, semistate and state) were examined. A significant link was found between the respondents' career anchors and corresponding job perception; after which a test for differences in quality of working life between the fit and non-fit group was carried out. It was only for those respondents whose dominant career anchor was job security that significant differences $(p<0,5)$ were found and the fit group had a significantly higher score. The implications of these findings on career planning for the individual and the firm are examined.
\end{abstract}

\section{OPSOMMING}

Die loopbaanankers en pospersepsie van 'n steekproef van 258 werknemers in verskillende tipes organisasies (privaat, semi-staat en staat) is ondersoek. 'n Betekenisvolle verband is tussen die proefpersone se loopbaanankers en pospersepsie verkry, waarna vir verskille in gehalte van werklewe tussen die passings- en nie-passingsgroep getoets is. Dit is slegs by daardie respondente waar die dominante loopbaananker werksekuriteit is dat beduidende verskille $(p<0,05)$ gevind is en die passingsgroep ' $n$ beduidende hoër telling behaal het. Die implikasies van die bevindings ten opsigte van loopbaanbeplanning vir die individu en onderneming word bespreek.

Sielkundiges beywer hulle al dekades daarvoor om 'n suksesvolle passing tussen individu en beroep te verkry. Soveel navorsing is al met betrekking tot aanleg, belangstelling en persoonlikheid gedoen ten einde persone in die korrekte beroep te plaas, maar steeds ondervind individue loopbaankrisisse en -verwarring. Dit mag wees dat individuele behoeftes en waardes nie genoegsaam by loopbaanbeplanning in aanmerking geneem word nie. Verskeie sielkundige toetse word daagliks vir loopbaanpassing aangewend en alhoewel hierdie toetse waardevolle inligting aan applikante met betrekking tot hulle profiele verskaf, slaag dit tog nie daarin om talente, motiewe, behoeftes en waardes op 'n baie suksesvolle manier te identifiseer nie. Dit wil dan voorkom asof ' $n$ individu se loopbaananker, soos deur Schein beskryf, moontlik 'n verdere bydrae tot die proses van loopbaanpassing kan maak.

Die begrip loopbaananker is die produk van 'n longitudinale studie wat Schein in die vroeë sestigerjare op 44 proefpersone onderneem het om die ontwikkeling van bestuursloopbane te ondersoek. Die doel was om spesifieke loopbaanpatrone en redes vir loopbaanbesluitneming te identifiseer. Schein het bevind dat mense aan die begin geneig is om slegs geïnteresseerd te wees in uitdagende werk, meer geld en meer verantwoordelikheid. $\mathrm{Na}$ ' $\mathrm{n}$ aantal jare se ervaring neig die individu na 'n spesifieke tipe werk of verantwoordelikheid waartoe hy aangetrokke voel. Elke individu bekom mettertyd meer selfkennis en ontwikkel ' $n$ duideliker konsep van sy beroep. Temas soos - "dit is ek" en "dit is nie ek nie" gebaseer op vroeë loopbaanjare het veral na aanleiding van Schein se bevindinge na vore gekom. Die konsep loopbaananker, soos deur Schein (1978, p. 125) beskryf, behels die volgende drie komponente:

- Die individu se siening van sy talente en vermoëns gebaseer op' $n$ aantal suksesse in 'n verskeidenheid werksaktiwiteite.

- Die individu se siening omtrent sy motiewe en behoeftes gebaseer op geleenthede om selfdiagnose en selftoetsing in ' $n$ werklike situasie toe te pas, asook op die terugvoering van ander.

- Die individu se siening van sy houdings en waardes, gebaseer op werklike ondervindings, en die norme en waardes van die organisasie en die werksomstandighede.
Die begrip loopbaananker beklemtoon evolusie, ontwikkeling en ontdekking deur werklike ervaringe. Die waarde van die loopbaanankerkonsep word weerspieël deur Schein (1985) as hy noem dat ' $n$ individu se loopbaananker, daardie waarde is wat hy nie sal prysgee wanneer hy met 'n loopbaankeuse gekonfronteer word nie. Opsommend noem Schein (1978) dat die loopbaananker in ' $n$ persoon se werklewe funksioneer as 'n wyse om ondervinding te organiseer, die individu se bydraes op die lang termyn te identifiseer, en om kriteria daar te stel vir tipes van werkomgewings waarbinne die individu graag wil funksioneer. Dit dien ook as kriteria vir sukses waaraan die individu homself wil meet. 'n Beskrywing van die verskillende tipe loopbaanankers, soos voorsien deur Schein (1985), word vervolgens gegee:

\section{- Sekuriteit, stabiliteit of organisatoriese identiteit} Sommige individue ervaar dat hulle ' $n$ oorheersende behoefte daaraan het om hulle loopbane in so 'n mate te organiseer dat hulle veilig en geborge voel, dat toekomstige gebeurtenisse voorspelbaar moet wees, en dat hulle kan ontspan in die wete dat hulle dit "gemaak het" en iewers hoort. Elkeen het ' $n$ behoefte aan die een of ander graad van sekuriteit en stabiliteit, maar vir party mense word dit egter 'n oorheersende sentrale kwessie wat alle loopbaanbesluite te alle tye begin stuur en inperk. Daar is ten minste twee tipes mense geïdentifiseer wie se loopbane in sekuriteitsbelange geanker is. Die een tipe is absoluut lojaal aan die organisasie en laat die verantwoordelikheid van loopbaanbestuur aan die organisasie oor, terwyl die ander tipe hom aan 'n geografiese area verbind en eerder van organisasie sal verander as om van omgewing te verander. So sal 'n individu met Sekuriteit as loopbaananker stabiele, voorspelbare werk kies en is hy meer gemoeid met die inhoud as die aard van die werk. Werkverryking, uitdagings en ander intrinsieke motivering is minder belangrik as ekstrinsieke faktore soos verhoogde salaris, werkstoestande en byvoordele.

\section{- Outonomie en onafhanklikheid}

Sommige individue kom vroeg in hul loopbaan reeds tot die besef dat hulle hulself moeilik onderwerp aan prosedures, werkure, kodes met betrekking tot kleredrag, andere se reëls asook norme wat onvermydelik in die meeste organisasies voorkom. Hulle ervaar dat wat ook al die area is waarin hulle 
werk, hulle ' $n$ behoefte het om dinge op hulle eie manier, teen hul eie tempo, en volgens eie standaarde te doen. Hulle vind die organisatoriese lewe beperkend, irrasioneel en/of bemoeiend met hulle private lewe en verkies derhalwe om hulle loopbane ooreenkomstig hulle eie bepalings te beoefen. Die individu met Outonomie as loopbaananker verkies werk met duidelik geformuleerde doelwitte, maar waar die wyse waarop dit bereik word aan die individu oorgelaat word. Hy hou nie van streng toesighouding nie, maar verbind hom tot doelwitte en sodra dit gestel is, verkies hy om op sy eie voort te gaan.

\section{- Kreatiwiteit en ondernemerskap}

Ander individue ontdek weer vroeg in hulle loopbaan dat hulle ' $n$ oorheersende behoefte het om onder andere 'n nuwe onderneming te stig, 'n nuwe produk of diens te ontwikkel, 'n nuwe organisasie deur finansiële manipulasie te stig of om ' $n$ bestaande onderneming oor te neem en te hervorm. Hierdie behoeftes moet nie met outonomie verwar word nie, aangesien dit hier gaan om dit wat ontwikkel of daargestel word in die vorm van 'n nuwe besigheid, produk of diens - dit is moontlik dat outonomie ingeboet sal word om dit te bereik. Kenmerkend van hierdie persone is dat hulle reeds vroeg in hulle loopbaan hulle ideale begin nastreef. Die meeste begin alreeds op hoërskool met klein ondernemings. Die individu met Entrepreneurskap as loopbaananker het 'n preokkupasie om iets kreatiefs te ontwikkel. As hy in sy eie onderneming is, sal hy voortdurend nuwe produkte en dienste bedink, of belangstelling verloor in die besigheid, dit verkoop en 'n nuwe een begin.

\section{- Tegniese/funksionele bevoegdheid}

Namate hulle loopbane ontwikkel en hulle in bepaalde werkareas inbeweeg, ontdek sommige individue dat hulle die vermoë het en hoogs gemotiveerd is vir 'n bepaalde tipe werk. Persoonlike bekwaamheid in ' $n$ bepaalde vakgebied of werksterrein is vir hierdie individue baie belangrik en die behoefte om hulle vaardigheid uit te oefen en bekend te maak, stel alle ander tipes behoeftes en belange ondergeskik daaraan. Die individu met ' $n$ Tegniese/funksionele loopbaananker verwag primêr uitdagende werk. Indien die werk nie die individu se vermoëns beproef nie, raak hy gou verveeld. Hierdie persone fokus veral op die intrinsieke inhoud van die werk.

\section{- Bestuursbevoegdheid}

Sommige individue ontdek, namate hulle loopbaan ontplooi, dat hulle in die bestuurshiërargie wil inbeweeg, dat bestuur op sigself hulle interesseer, dat hulle opgewasse is daarvoor, en dat hulle ' $n$ vlak in die organisasie wil bereik waar hulle bestuursoptrede die verskil tussen sukses of mislukking kan maak. Vir hierdie groep mense is vooruitgang, hoë vlakke van verantwoordelikheid, die geleentheid om ' $n$ bydrae te lewer tot die welsyn van hulle organisasies, leierskapgeleenthede en 'n hoë inkomste belangrike waardes wat aan 'n pos gekoppel word. Dit dien as hulle maatstaf vir sukses. By hierdie individue is analitiese, interpersoonlike en emosionele vaardighede noodsaaklik vir doeltreffende funksionering.

\section{- Dienslewering of toewyding aan 'n saak}

Sommige individue bou 'n beroep uit rondom die een of ander sentrale waarde. Diensbaarheid is 'n belangrike oorweging vir hierdie mense. Om vermoëns en vaardighede aan 'n bepaalde saak toe te wy is van primêre belang met die vergoeding en erkenning daaraan verbonde, dikwels sekondêr. Daar word verwag dat bydraes erken word en toegang verkry kan word tot poste met meer invloed en vryheid.

\section{- Suiwer uitdaging}

Sommige individue omskryf hulle loopbane in terme van die suiwer uitdaging wat betrokke is. Hulle is oorwegend begaan daaroor om 'n oorwinning oor ander te behaal of struikelblokke te oorkom. Hulle omskryf sukses as die bemeestering van struikelblokke, die oplos van moeilike probleme, of 'n oorwinning oor uiters moeilike teenstanders, en is voortdurend op soek na verdere veeleisende uitdagings. Hierdie persone het voortdurend ' $\mathrm{n}$ behoefte om in ' $\mathrm{n}$ wensituasie te wees.

\section{- Lewenstylintegrasie}

Sommige individue het 'n sterk behoefte daaraan om nie ' $n$ keuse te moet maak tussen gesinsake, loopbaansake, en sake met betrekking tot selfontwikkeling nie. Die basiese behoefte hier is om die komponente te integreer en 'n balans tussen die onderskeie lewensfasette soos gesinslewe, selfontwikkeling, ensovoorts te handhaaf. Loopbaanbesluite speel nie 'n oorheersende rol nie. Buigsaamheid met betrekking tot hierdie fasette is vir hierdie individue baie belangrik.

Die loopbaanankers soos bespreek, is waarskynlik by die meeste individue teenwoordig, maar elke individu het, volgens Schein (1985), 'n dominante loopbaananker wat loopbaanbesluitneming beïnvloed.

As die vermelde loopbaanankers waarin sekere waardes en behoeftes opgesluit is, dan dien om 'n loopbaan te rig en te beheer, behoort die verwagtings wat ' $n$ individu van sy werk koester onder andere die resultaat van die invloed van sy dominante loopbaananker te wees. Die integrasie van hierdie behoeftes en verwagtings kan moontlik 'n verdere bydrae tot pospassing maak. Die verskillende loopbaanankers omsluit dus spesifieke loopbaanbehoeftes van die individu. Of die bevrediging hiervan tydens pospassing enige resultate tot gevolg het, behoort ondersoek te word. Met die sluiting van die sielkundige kontrak kan oor hierdie behoeftes onderhandel word. Shmikler en Miller (1981) noem dat die rasionaal van loopbaanankers nou verbind is met die bestaan van sielkundige kontrakte en die passing van wedersydse ondersteunende doelwitte asook verwagtings tussen individue en organisasies. Schein (1978) noem dat dit vir bestuurders belangrik is om die verskille tussen werknemers as gevolg van loopbaanankers te erken, sodat sielkundige kontrakte ontwikkel kan word wat die verwagtings van die individu akkommodeer.

Om te bepaal of die resultaat van die integrasie van loopbaanankerbehoeftes met die pos, spesifieke uitsette soos'n hoër gehalte van werklewe (GWL) tot gevolg het, word die sielkundige kontrak gebruik om die konsepte te integreer. By die sluiting hiervan behoort daar derhalwe oor loopbaanankerbehoeftes onderhandel te word. Aangesien daar nie werklik literatuur aangaande die verband tussen loopbaanankers, die passingsproses en GWL bestaan nie, word die reeds genoemde verband tussen die passingsproses en loopbaanankers, soos bespreek, as uitgangspunt vir hierdie studie geneem. Navorsing aangaande die verband tussen die sielkundige kontrak en werkstevredenheid word dus bespreek. Vir die doeleindes van die studie word daar nie werklik onderskeid tussen GWL en werkstevredenheid getref nie, aangesien vorige navorsers (Boisvert, 1977; Coetser, 1980) hoë korrelasies tussen hierdie konsepte gevind het.

Sommige skrywers (Kotter, 1973; Schein, 1988) beweer dat die resultaat van die instandhouding van die sielkundige kontrak, werkstevredenheid is. Kotter (1973) stel 'n model voor waarin hy aantoon dat hoe beter passing daar in die sielkundige kontrak is, hoe hoër sal werkstevredenheid wees. Sy eie navorsing het dan ook getoon dat by sielkundige kontrakte waar daar 'n passing tussen verwagtings is, groter werkstevredenheid, hoër produktiwiteit en laer arbeidsomset teenwoordig is. Schein (1988) noem dat individuele lojaliteit en entoesiasme vir 'n organisasie, asook werkstevredenheid, grootliks sal afhang van die mate van voldoening aan wedersydse verwagtings. Sielkundige kontrakte wat voorsiening maak vir die bevrediging van loopbaanankerbehoeftes behoort dus waarskynlik 'n hoër GWL tot gevolg te hê.

'n Hoër GWL beteken ook dat gemotiveerde gedrag by die werker bewerkstellig moet word. Motivering kan gesien word as 'n baie individuele funksie, iets wat tussen mense plaasvind en die belangrikheid van gesonde verhoudings beklemtoon. Voordat 'n gesonde verhouding ontwikkel kan word, moet daar eers 'n bouproses wees wat die vertroue skep en ontwikkel tussen werkgewer en werknemer. Volgens Mack (1976) is die uiteindelike doelwit van sodanige proses die sielkundige kontrak. Hiervolgens blyk dit dat indien organisasies die voorwaardes van die sielkundige kontrak nakom, dit bydra tot die motivering van werkers.

Die voorafgaande bespreking gee aanleiding tot ' $n$ model wat as volg voorgestel kan word. 


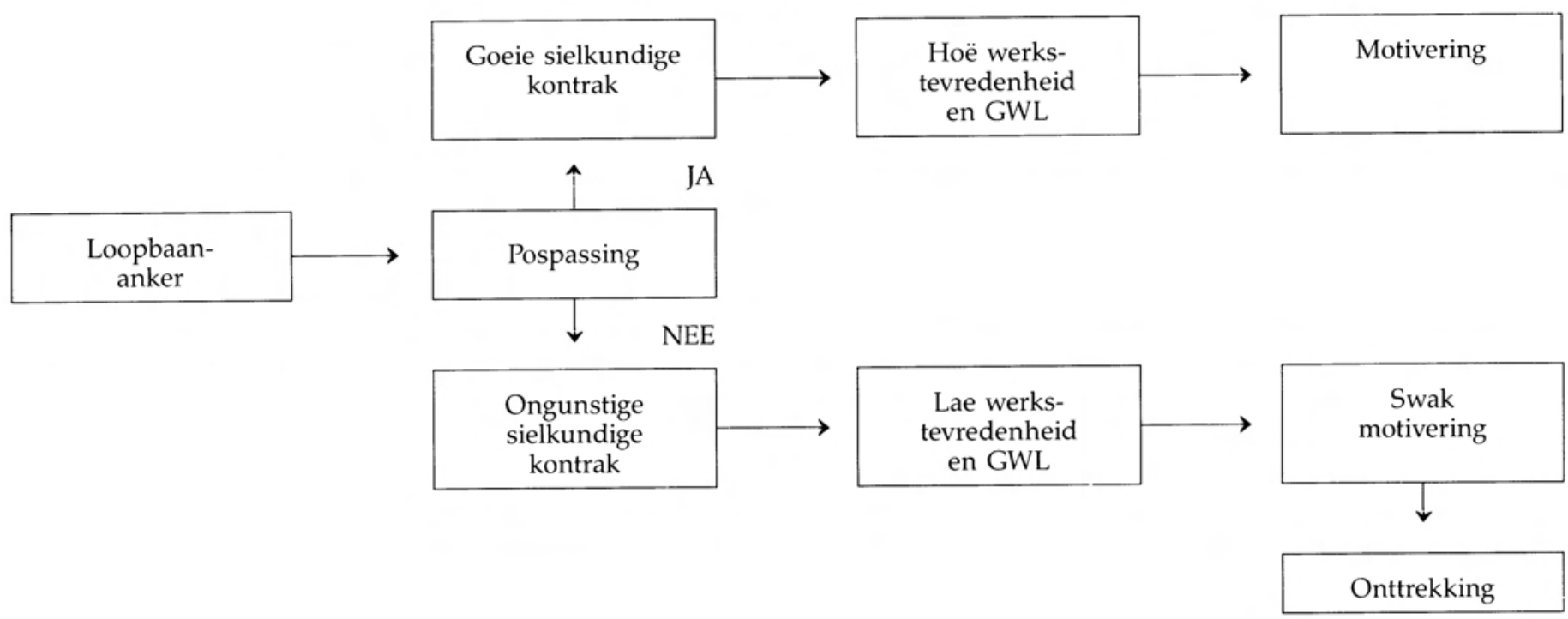

Figuur 1: 'n Model vir die verband tussen loopbaanankers, pospersepsie en gehalte van werklewe

Om te bepaal of die bevrediging van spesifieke loopbaanankerbehoeftes 'n hoër gehalte van werklewe tot gevolg het, behoort verdere perspektief op die loopbaanankerkonstruk te werp asook die aanwending daarvan in loopbaanbesluitneming. Navorsing oor die loopbaanankerkonstruk is nog slegs op beperkte skaal in Suid-Afrika onderneem. Vorige navorsers (Boshoff, Kaplan en Kellerman 1988; Erwee, 1988; Slabbert, 1987) het wel die dominante loopbaanankers van individue vir verskillende beroepe ondersoek. Van Vuuren (1989) het die verband tussen loopbaanankers en enkele persoonlikheidstrekke ondersoek. Hierdie navorsingsresultate asook dié van oorsese navorsers (Burke, 1983, 1985; Claire, 1983; Derr, 1980; Eastwood, 1981; Schein, 1975, 1978) beklemtoon die moontlike waarde van loopbaanankers binne die veld van die Bedryfsielkunde. Fottler en Bain (1984) meld dat om die verband tussen loopbaanstadiums, loopbaanbehoeftes, waardes en doelwitte en gehalte van werklewe te ondersoek, een van die mees waardevolle areas van navorsing in die toekoms mag word.

Teen die agtergrond van die voorafgaande bespreking is die volgende spesifieke doelstellings vir die studie gestel:

- Om te bepaal of daar ' $n$ verband tussen loopbaanankers en pospersepsie bestaan.

- Om te bepaal of GWL deur 'n passing tussen loopbaanankers en pospersepsie beïnvloed word.

Na aanleiding van hierdie doelstellings is die volgende hipoteses geformuleer:

- Daar bestaan 'n verband tussen loopbaanankers en pospersepsie.

- Die gehalte van werklewe van individue met 'n passing tussen loopbaanankers en pospersepsie verskil van dié van individue sonder 'n soortgelyke passing.

\section{METODE}

\section{Proefgroep}

258 Werknemers, ouer as 35 jaar en in verskillende organisasietipes (privaat, semi-staat, staat) is in die studie betrek. Ander belangrike kenmerke van die proefgroep was die volgende:

Die gemiddelde ouderdom was 43,5 jaar, 62,8 persent was manlik en 75,9 persent was Afrikaanssprekend. Een-en-sestig persent het oor 'n naskoolse kwalifikasie beskik. 'n Besondere kenmerk van die ondersoekgroep was 'n baie hoë werkstabiliteit. Ongeveer 45 persent het geen werksverandering die afgelope 10 jaar gemaak nie, en 26 persent het slegs een verandering gemaak.

\section{Meetinstrumente}

\section{- Biografiese vraelys}

Die vraelys is saamgestel met die doel om dié persoonlike inligting te bekom wat vir die beskrywing van die steekproef noodsaaklik was.

\section{- Career Orientations Inventory (COI)}

Die oorspronklike 41-item-vraelys van Schein (1985) is gebruik. Hierdie vraelys meet net sekere dimensies van 'n loopbaananker, naamlik individuele loopbaanhoudings, -waardes en -behoeftes wat as loopbaanoriëntasies gedefinieer word. Dit vorm egter'n sentrale gedeelte van 'n loopbaananker wat die samestelling van loopbaanoriëntasies (houdings, waardes, behoeftes) en selfwaargeneemde talente is (De Long, 1982). Hoewel in hierdie vraelys 'n Likert-tienpuntskaal gebruik word, is dit vir doeleindes van hierdie navorsing verander na ' $n$ vyfpuntskaal om in ooreenstemming met die ander meetinstrumente te wees. Die oorspronklike vraelys maak slegs van twee skaalpunte (glad nie en in 'n baie groot mate) gebruik en van die proefpersone word verwag om hul keuse op 'n tienpuntskaal tussen hierdie twee pole uit te oefen. Die vraelys wat vir hierdie navorsing gebruik is, gebruik die volgende vyfpuntskaal:

- glad nie, in 'n mindere mate, in 'n mate, in meerdere mate, in 'n baie groot mate.

Die geldigheid van die vraelys is deur De Long (1984), Slabbert (1987) en Boshoff (1988) ondersoek. Hierdie navorsers rapporteer dat die items wel so ontwerp is dat dit die verskillende loopbaanankers meet. Nadat betroubaarheidskoëffisiënte deur De Long (1982) en Boshoff (1988) bereken is, kom hul tot die gevolgtrekking dat alhoewel daar verdere ontwikkelingswerk noodsaaklik is om die vraelys se psigometriese kwaliteite te verhoog, die betroubaarheid as voldoende beskou word om navorsing ten opsigte van sekere verbande en tendense te regverdig.

\section{- Pospersepsievraelys}

Om te kon bepaal of daar 'n passing tussen loopbaananker en pospersepsie is, is hierdie vraelys so ontwikkel dat dit die proefpersone se persepsie van hulle poste ten opsigte van dieselfde faktore as die COI meet. Deur die proefpersoon se persepsie van sy pos te meet, word in werklikheid van hom verwag om 'n beskrywing van sy eie pos te gee en behoort die werklike eienskappe van die pos soos deur die posbekleër beleef, grootliks hierdeur gereflekteer te word. Om 'n werklike passing tussen 'n individu se loopbaananker en sy pos te verkry, is die persepsie wat 'n individu van sy pos het 'n bepalende faktor. ' $n$ Pos mag die behoeftes van verskeie ankers bevredig, wat impliseer dat die meeste poste of beroepe nie 'n unieke anker behoort te hê nie. As 'n individu se persepsie van sy pos dus ooreenstem met die kenmerke van sy anker, 
kan passing ervaar word. Die items van die COI is in so 'n mate herskryf dat 'n meting van 'n individu se persepsie van sy pos vir elk van die nege ankers verkry kon word. Hierdie vraelys bestaan soos die COI ook uit 41 items met 'n vyfpuntskaal, waarop proefpersone moes reageer.

Aangesien die vraelys nog nie voorheen gebruik is nie, is vorige resultate met betrekking tot betroubaarheid nie beskikbaar nie. Cronbach se Alfa-koëffisiënt is bereken vir elkeen van die faktore en die resultate word in Tabel 1 aangetoon. Die Alfa-koëffisiënte is bevredigend, behalwe Geografiese Sekuriteit en Entrepreneur wat laag is. Wat Geografiese Sekuriteit betref, meet slegs drie items die faktor - wat ' $n$ invloed op betroubaarheid mag hê. Verder is die standaardafwyking vir die itemtellings laag in verhouding tot die standaardafwyking van die totale telling. Die verband tussen item 41 en die totaal is baie laag. Hierdie faktor is by die vertolking van die resultate buite rekening gelaat.

TABEL 1

FAKTORE EN ALFA-KOËFFISIËNTE

\begin{tabular}{|l|c|c|}
\hline FAKTOR & $\begin{array}{c}\text { AANTAL } \\
\text { ITEMS }\end{array}$ & ALFA-KOËFFISIËNTE \\
\hline Tegnies/funksioneel & 5 & 0,80 \\
Bestuursbekwaamheid & 5 & 0,80 \\
Outonomie & 5 & 0,84 \\
Werksekuriteit & 3 & 0,94 \\
Geografiese Sekuriteit & 3 & 0,09 \\
Diens & 5 & 0,82 \\
Suiwer Uitdaging & 5 & 0,76 \\
Lewenstylintegrasie & 5 & 0,81 \\
Entrepreneur & 5 & 0,48 \\
\hline
\end{tabular}

Behalwe dié twee faktore, kan aanvaar word dat, volgens die Alfa-koëffisiënte, die betroubaarheid van die vraelys aanvaarbaar is.

Om die interne konsekwentheid van hierdie vraelys te bepaal, is ' $n$ item-totaal-korrelasie vir elke faktor uitgevoer.

Tabel 2 toon die item-faktor-korrelasies vir die Pospersepsievraelys.

TABEL 2

ITEM-FAKTOR-KORRELASIES VIR DIE POSPERSEPSIEVRAELYS

\begin{tabular}{|l|r|r|}
\hline FAKTOR & ITEMS & $\mathrm{r}$ \\
\hline Tegnies/funksioneel & 1 & 0,70 \\
& 9 & 0,38 \\
& 17 & 0,85 \\
Bestuursbekwaamheid & 33 & 0,58 \\
& 25,85 \\
& 10 & 0,81 \\
Outonomie & 18 & 0,76 \\
& 26 & 0,83 \\
& 34 & 0,79 \\
& 3 & 0,54 \\
Werksekuriteit & 11 & 0,70 \\
& 19 & 0,69 \\
Geografiese Sekuriteit & 27 & 0,66 \\
& 35 & 0,77 \\
& 4 & 0,63 \\
Diens & 12 & 0,93 \\
& 36 & 0,94 \\
& 20 & 0,96 \\
& 28 & 0,80 \\
& 41 & 0,83 \\
& 5 & 0,11 \\
& 21 & 0,73 \\
& 29 & 0,78 \\
& 37 & 0,82 \\
& & 0,77 \\
& & 0,74
\end{tabular}

\begin{tabular}{|l|r|c|}
\hline FAKTOR & ITEMS & r \\
\hline Suiwer Uitdaging & 6 & 0,59 \\
& 14 & 0,75 \\
& 22 & 0,70 \\
& 30 & 0,76 \\
Lewenstylintegrasie & 38 & 0,75 \\
& 7 & 0,66 \\
& 15 & 0,79 \\
& 23 & 0,74 \\
Entrepreneur & 31 & 0,78 \\
& 39 & 0,79 \\
& 8 & 0,76 \\
& 16 & 0,38 \\
& 24 & 0,56 \\
& 32 & 0,67 \\
& 40 & 0,52 \\
\hline
\end{tabular}

Volgens hierdie tabel is die item-faktor-korrelasies deurgaans redelik hoog, behalwe ten opsigte van die reeds vermelde korrelasie tussen item 41 en die faktor Geografiese Sekuriteit. Hierdie item soos wat dit in die vraelys voorkom, meet dus nie hierdie faktor betroubaar en geldig nie.

- Organisasiediagnosevraelys (ODV)

Hierdie vraelys gebruik 'n vyfpuntskaal en bestaan uit verskillende hooffaktore en 'n aantal subfaktore, met die doel om individuele houdings en persepsies te bepaal. Aangesien die doel van hierdie navorsing was om te bepaal of 'n passing tussen loopbaanankers en pospersepsie ' $n$ betekenisvolle hoër gehalte van werklewe tot gevolg het, was 'n omvattende meting van hierdie aspek noodsaaklik. Die ODV verkry metings op verskeie dimensies van GWL. Die verskillende faktore word nie afsonderlik in die studie betrek nie, maar slegs 'n saamgestelde telling wat die GWL van elke proefpersoon reflekteer, word gebruik. Vorige navorsers (Coetser, 1980; Coster, 1981; Van Pletsen, 1986) het die betroubaarheid en geldigheid van die vraelys bevestig. Die vraelys is ook deur bogenoemde navorsers in ondersoeke gebruik.

\section{- Metode van dataversameling}

Die vraelyste is by elk van die nege betrokke maatskappye versprei. Aangesien die vraelyste baie lywig was ( 42 bladsye) is 'n kontakpersoon in die organisasie gebruik om met die verspreiding te help. Al die vraelyste is met 'n dekbrief aan die proefpersone beskikbaar gestel. In die dekbrief is die doel van die ondersoek uitgespel, anonimiteit gewaarborg en samewerking versoek. Aan die proefpersone is die versekering gegee dat geen individuele terugvoering aan die onderskeie werkgewers gegee sal word nie. Sover dit met so 'n tipe ondersoek moontlik is, is verseker dat betroubare inligting bekom is. Die proefpersone is versoek om die voltooide vraelyste naamloos in 'n verseëlde koevert aan die kontakpersoon terug te stuur, by wie die navorser dit weer afgehaal het. Die funksie van die kontakpersoon was hoofsaaklik om die proefpersone aan te moedig met die voltooiing. Hierdie persoon was deurgaans 'n onafhanklike persoon en nie die onmiddellike hoof van die proefpersone nie. Op hierdie wyse is ' $n$ terugvoer van 86 persent bewerkstellig.

\section{RESULTATE EN BESPREKING}

Om te kon bepaal of daar ' $n$ verband tussen loopbaanankers en pospersepsie is, moes proefpersone se dominante loopbaananker asook die ooreenstemmende persepsie van hulle poste verkry word. Hierdie metings is onderskeidelik met die $\mathrm{COI}$ en die Pospersepsievraelys verkry. Om die verband te bepaal is telkens die dominante loopbaananker met die ooreenstemmende persepsie vergelyk om te bepaal of daar 'n passing is al dan nie. Die finale statistiese toetsing is met behulp van die Chi-kwadraattoets gedoen. Tabel 3 toon die verband (Chi-kwadraatwaardes) tussen loopbaanankers en pospersepsies. 
TABEL 3

DIE VERBAND TUSSEN LOOPBAANANKERS EN POSPERSEPSIES VIR DIE TOTALE GROEP (CHI-KWADRAATTELLINGS)

\begin{tabular}{|c|c|c|c|c|c|c|c|}
\hline \multicolumn{7}{|c|}{ LOOPBAANANKERS/POSPERSEPSIES } \\
\hline $\begin{array}{c}\text { TEGNIES/ } \\
\text { FUNKSIONEEL }\end{array}$ & $\begin{array}{c}\text { BESTUURSBE- } \\
\text { KWAAMHEID }\end{array}$ & OUTONOMIE & $\begin{array}{c}\text { WERK- } \\
\text { SEKURITEIT }\end{array}$ & DIENS & $\begin{array}{c}\text { SUIWER } \\
\text { UITDAGING }\end{array}$ & $\begin{array}{c}\text { LEWENSTYL } \\
\text { ENTREPRE- } \\
\text { NEUR }\end{array}$ \\
\hline $5,826 * *$ & 2,078 & - & $26,912 * * *$ & $27,358 * * *$ & $20,168 * * *$ & $23,336 * * *$ & - \\
\hline
\end{tabular}

${ }^{*} \mathrm{p}<0,05 \quad{ }^{* *} \mathrm{p}<0,02 \quad{ }^{* * *} \mathrm{p}<0,01$

Samevattend kan genoem word dat oorwegend 'n betekenisvolle verband tussen die dominante loopbaananker en die ooreenstemmende persepsie verkry is. Wat Outonomie en Entrepreneur betref het te min proefpersone hierdie ankers as dominant aangetoon om 'n Chi-kwadraat te regverdig. 'n Groot persentasie (58,9\%) proefpersone het met Werksekuriteit as loopbaananker geassosieer en 32,2 persent met Diens wat die interpretasie van die resultate ietwat bemoeilik het.
Om te kon bepaal of daar 'n verband tussen loopbaanpassing en gehalte van werklewe is, is die verskille tussen die GWL-tellings van dié proefpersone met 'n passing tussen loopbaananker en pospersepsie (passingsgroep) en dié proefpersone met nie 'n sodanige passing nie (nie-passingsgroep) bereken. Om te bepaal of daar beduidende verskille is, is van t-toetse gebruik gemaak. Tabel 4 toon die gemiddelde GWLtellings van die passings- en nie-passingsgroep.

TABEL 4

DIE GEMIDDELDE GWL-TELLINGS VAN DIE PASSING- EN NIE-PASSINGSGROEP TEN OPSIGTE VAN LOOPBAANANKERS EN POSPERSEPSIES VIR DIE TOTALE GROEP

\begin{tabular}{|c|c|c|c|c|c|c|c|c|}
\hline & \multicolumn{9}{|c|}{ PASSINGSGROEP } & \multicolumn{3}{c|}{ NIE-PASSINGSGROEP } & & \\
\cline { 2 - 9 } & $\mathrm{N}$ & $\begin{array}{c}\overline{\mathrm{X}} \text {-GWL } \\
\text { TELLING }\end{array}$ & $\mathrm{S}$ & $\mathrm{N}$ & $\begin{array}{c}\overline{\mathrm{X}} \text {-GWL } \\
\text { TELLING }\end{array}$ & $\mathrm{S}$ & F-WAARDE & t-WAARDE \\
\hline TOTALE GROEP & 157 & 3,7213 & 0,5130 & 101 & 3,6036 & 0,4278 & $4,29^{\star}$ & 1,92 \\
\hline
\end{tabular}

* $\mathrm{P}<0,05 \quad$ ** $\mathrm{P}<0,02 \quad$ *** $\mathrm{P}<0,01$

Volgens hierdie tabel is daar geen betekenisvolle verskil tussen die GWL-tellings van die twee groepe nie.

Daar is ook besluit om te toets of die GWL-tellings statisties tussen die passing en nie-passingsgroep by die dominantste loopbaanankers verskil. Vir hierdie doel is slegs Diens en Werksekuriteit gebruik. In tabel 5 word die gemiddelde GWLtellings van die passings- en nie-passingsgroep ten opsigte van Diens en Werksekuriteit vir die totale groep aangetoon.

TABEL 5

DIE GEMIDDELDE GWL-TELLINGS VAN DIE PASSING- EN NIE-PASSINGSGROEP TEN OPSIGTE VAN DIENS EN WERKSEKURITEIT

\begin{tabular}{|l|c|c|c|c|c|c|c|c|}
\hline & \multicolumn{3}{|c|}{ PASSINGSGROEP } & \multicolumn{3}{c|}{ NIE-PASSINGSGROEP } & \multicolumn{2}{c|}{} \\
\hline LOOPBAANANKER & $\mathrm{N}$ & $\begin{array}{c}\overline{\mathrm{X}} \text {-GWL } \\
\text { TELLING }\end{array}$ & $\mathrm{S}$ & $\mathrm{N}$ & $\begin{array}{c}\bar{X}-\text {-GWL } \\
\text { TELLING }\end{array}$ & $\mathrm{S}$ & F-WAARDE & t-WAARDE \\
\hline Diens & 28 & 3,8578 & 0,5731 & 230 & 3,6530 & 0,4686 & 2,54 & 1,82 \\
\hline Werksekuriteit & 132 & 3,7327 & 0,5042 & 126 & 3,6150 & 0,4561 & 1,13 & $1,97^{*}$ \\
\hline
\end{tabular}

${ }^{*} \mathrm{P}<0,05 \quad$ ** $\mathrm{P}<0,02 \quad * * * \mathrm{P}<0,01$

Hiervolgens is daar slegs beduidende verskille $(p<0,05)$ by die proefpersone met ' $\mathrm{n}$ dominante loopbaananker van Werksekuriteit. Die passingsgroep het ' $n$ beduidende hoër telling as die nie-passingsgroep behaal. Die afleiding wat hieruit gemaak kan word, is dat die proefpersone met Werksekuriteit as 'n dominante loopbaananker en wat ook hulle pos as ooreenstemmend ervaar oor die algemeen 'n hoër GWL het as die groep wat nie so 'n passing het nie.

\section{GEVOLGTREKKING}

- 'n Individu ondervind oorwegend ' $n$ passing tussen sy dominante loopbaananker en ooreenstemmende pospersepsie.

- 'n Individu met 'n passing tussen sy dominante loopbaananker en die persepsie wat hy van sy pos het, ervaar moontlik 'n hoër gehalte van werklewe. 'n Beter aanduiding van die mate waartoe loopbaanpassing gehalte van werklewe beïnvloed, behoort verkry te word wanneer ander veranderlikes, soos byvoorbeeld hiërargiese vlakke en loopbaanfases, wat hierdie verband moontlik kan beïnvloed in aanmerking geneem word. Loopbaanankers mag meer belangrik raak met loopbaanontplooiing.

- Om 'n passing tussen postipe en individuele behoeftes te verkry, kan moontlik individuele- en organisasievoordele tot gevolg hê.

- Die voorspellingsgeldigheid van sielkundige toetse is dikwels ' $n$ probleem en moontlik kan hierdie leemte met die benutting van loopbaanankers in die keuringsproses aangevul word.

- Die gehalte van werklewe van werkers kan moontlik verhoog word deur loopbaanankers in hierdie verband te benut.

- Soos wat ' $n$ individu se verwagtings van sy pos die resultaat van die invloed van sy dominante loopbaananker kan wees, behoort die verwagtings wat hy van sy organisasie koester ook die resultaat daarvan te wees. Verdere navorsing in hierdie verband word aanbeveel. 


\section{BRONNELYS}

Boisvert, M.P. (1977). The quality of working life: an analysis. Human Relations, 84(2), 155-160.

Boshoff, A.B., Kaplan, R.A., \& Kellerman, A.M. (1988). The career anchors of members of fourteen professions in South Africa. Ongepubliseerde manuskrip, Universiteit van Pretoria, Pretoria.

Burke, R.M. (1983). Career orientations of type A individuals. Psychological Reports, 53, 979-989.

Burke, R.M. (1985). Career orientations of type A behavior in police officers. Psychological Reports, 57, 1239-1246.

Claire, A.R. (1983). The career anchor of selected groups of nurses. Ph.D.-thesis, University of Utah, Salt Lake City.

Coetser, R. (1980). Individuele werkverwagtings as maatstaf vir die bepaling van die gehalte van werklewe vir programmeerders. Ongepubliseerde M.Com.-verhandeling, Universiteit van Suid-Afrika, Pretoria.

Coster, E.A. (1981). Organizational development: the implementation and evaluation of a survey-guided feedback intervention. Ongepubliseerde M.Com.-verhandeling, Universiteit van Suid-Afrika, Pretoria.

De Long, T.J. (1982). Reexamining the career anchor model. Personnel, 59(3), 50-61.

De Long, T.J. (1984). A comparison of the career orientations of rural and urban educators. Educational Review, 36(1), 67-74.

Derr, C.B. (1980). Work, family and the career. New York: Praeger Publishers.

Eastwood, K. (1981). Career anchors, job satisfaction and selfesteem. Dissertation Abstracts International, 41(9), 3617.

Erwee, R. (1988). Career orientations of business and professional women. Ongepubliseerde manuskrip, Universiteit van Pretoria, Pretoria.

Fottler, M.D. \& Bain, T. (1984). Realism of occupational choice among high school seniors: implications for quality of work life. Journal of Occupational Behaviour, 5(4), 237-251.

Kotter, J.P. (1973). The psychological contract: Managing the joining-up process. California Management Review, 15(3), 91-99.

Mack, H. (1976). Some lessons in motivation. Supervisory Management, 21(8), 3-8.

Schein, E.H. (1975). How "career anchors" hold executives to their career paths. Personnel, 52(3), 11-24.

Schein, E.H. (1978). Career dynamics: matching individual and organizational needs. Philippines: Addison Wesley Publishing Co.

Schein, E.H. (1985). Career anchors: discover your real values. San Diego: University Associates.

Schein, E.H. (1988). Organizational psychology. Englewood Cliffs, New Jersey: Prentice Hall.

Shmikler, S. \& Miller, C. (1981). The model of career anchors as a tool in the analysis of instructional developers. National Society for Performance and Instructional Journal, 20(6), 18-23.

Slabbert, I. (1987). An evaluation of the management training and career anchors of $M B A / M B L$ graduates. Pretoria: Human Sciences Research Council.

Van Pletsen, F. (1986). Die interafhanklikheid van gehalte van werklewe, werkwaardes en werkverwagtings. Ongepubliseerde D.B.A.-proefskrif, Universiteit van Pretoria, Pretoria.

Van Vuuren, P.L. (1989). Die verband tussen loopbaanankers en enkele persoonlikheidstrekke. Ongepubliseerde M.Com.-verhandeling, Universiteit van Suid-Afrika, Pretoria. 